\title{
28 Research Square

\section{Machine Learning Algorithms and Whole Exome Sequencing Data from Breast Cancer Patients in the UK Biobank Predict Survival}

Research article

Keywords:

Posted Date: December 8th, 2020

DOI: https://doi.org/10.21203/rs.3.rs-115867/v2

License: (c) (1) This work is licensed under a Creative Commons Attribution 4.0 International License.

Read Full License

Version of Record: A version of this preprint was published at Biomarkers in Medicine on November 1st, 2021. See the published version at https://doi.org/10.2217/bmm-2021-0280. 


\section{Abstract}

The authors have requested that this preprint be withdrawn due to erroneous posting.

\section{Full Text}

The authors have withdrawn this preprint from Research Square. 